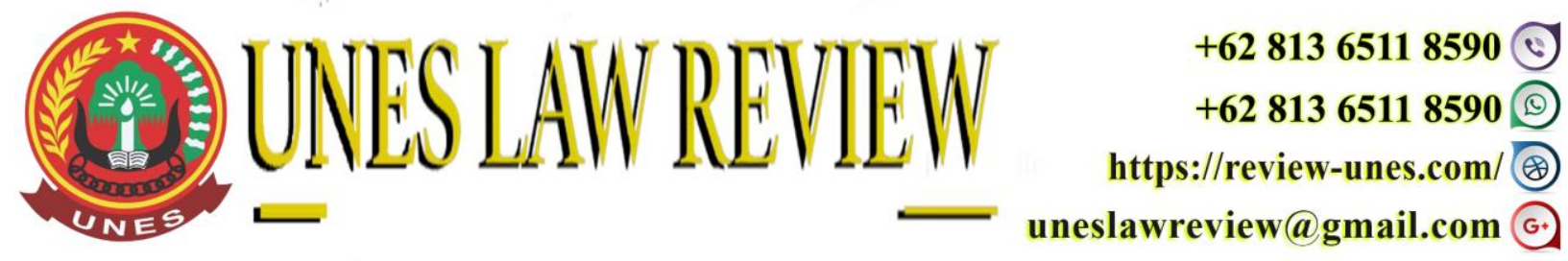

DOI: https://doi.org/10.31933/unesrev.v4i3

Diterima: 23/02/2022, Diperbaiki: 25/02/2022, Diterbitkan: 01/03/2022

\title{
TINJAUAN YURIDIS TERHADAP PERLINDUNGAN HUKUM BAGI PENGGUNA JASA PINJAMAN ONLINE ILEGAL DI INDONESIA
}

\author{
Eko Pratama Sinaga ${ }^{1}$, Abdurrakhman Alhakim ${ }^{2}$ \\ 1) Fakultas Hukum, Universitas Internasional Batam, Indonesia. \\ Email:1951080.eko@uib.edu \\ 2) Fakultas Hukum, Universitas Internasional Batam, Indonesia. \\ Email: 1951080.eko@uib.edu
}

Corresponding Author: Eko Pratama Sinaga

\section{ABSTRACT}

Looking at the development of technology that is so fast and also used in all fields to provide convenience. This also includes electronic transactions on online loan applications (pinjol), given the current economic conditions that are not in a good condition due to Covid-19, many people choose loan applications to meet their needs without seeing the overall consequences of their actions. The case of a pinjol application that attacks the personal data of its users is of course a prohibited act because it is related to someone's personal data. This study aims to find out how the legal protection for illegal loan service users in Indonesia is and what are the obstacles to law enforcement in dealing with loan lending cases in Indonesia. This research uses normative legal research methods. And it is known that in Indonesia, about criminal law policies that can be used to punish debtors for their actions, they can use UUPK because of the position of borrowing users as consumers and use the ITE Law because transactions are carried out using electronic media. The obstacles that occur are the lack of experts in the field of electronics in law enforcement and also the ITE Law is not strong enough to ensnare borrowers.

Keywords: Online Loans (Pinjol), Criminal Policies, Electronic Transactions

\begin{abstract}
ABSTRAK
Melihat kepada perkembangan teknologi yang begitu cepat dan juga dimanfaatkan segala bidang untuk memberikan kemudahan. Hal ini juga termasuk transaksi eletronik pada aplikasi pinjaman online (pinjol), mengingat kondisi ekonomi saat ini yang sedang dalam keadaan tidak baik akibat Covid-19 maka banyak masyarakat memilih aplikasi pinjol untuk memenuhi kebutuhannya tanpa melihat secara keseluruhan akibat dari perbuatannya. Kasus aplikasi pinjol yang menyerang data pribadi penggunanya tentunya hal tersebut merupakan perbuatan yang dilarang, karena berkaitan dengan data pribadi seseorang. Penelitian ini bertujuan untuk mengetahui bagaimana bagaimana perlindungan hukum terhadap pengguna jasa pinjol ilegal di Indonesia dan apa hambatan penegak hukum dalam menangani kasus pinjol di Indonesia. Penelitian ini menggunakan metode
\end{abstract}


penelitian hukum normatif. Dan diketahui bahwa di Indonesia berkaitan dengan kebijakan hukum pidana yang dapat digunakan untuk mengukum pelaku pinjol atas perbuatannya dapat menggunakan UUPK karena kedudukan pengguna pinjol sebagai konsumen dan menggunakan UU ITE karena transaksi dilakukan menggunakan media elektronik. Adapaun hambatan yang terjadi yaitu kurangnya tenaga ahli dalam bidang elektronik dipenegak hukum dan juga UU ITE tidak cukup kuat untuk menjerat pelaku pinjol.

Kata Kunci: Pinjaman Online (Pinjol), Kebijakan Pidana, Transkasi Elektronik

\section{PENDAHULUAN}

Kemajuan teknologi dalam hal ini menjadi suatu hal yang mendasari perkembangan disegala bidang, dan termasuk dalam bidang pelayanan jasa keuangan. Dan dalam hal ini di kehidupan manusia tidak terlepas dari yang namanya transaksi keuangan dan atau kegiatan ekonomi dalam memenuhi kebutuhan satu sama lain. Dalam hal ini terkait dengan beberapa kemudahan yang diperoleh untuk menjalankan suatu aktivitas merupakan suatu keuntungan yang didapat oleh manusia dengan adanya suatu teknologi tersebut dimana teknologi tersebut juga memanfaatkan informasi sehingga menjadi suatu teknologi informasi. Macam dalam hal ini Ini salah satu perkembangan tersebut yaitu pada sektor finansial yang mana dalam hal ini juga dapat ditemukan pada peer to peer lending finance technology (fintech) Atau di Indonesia sering disebut dengan suatu parfum pinjaman online yang mana hal tersebut juga biasa disebut oleh masyarakat sebagai pengguna pinjaman online tersebut yaitu sebagai layanan pinjaman online atau pinjol. ${ }^{1}$ Saat ini ini dalam hal penggunaan suatu layanan keuangan yang dapat dihubungkan dengan pinjol tersebut sangat banyak digunakan oleh para pengguna pinjol karena melihat kepada situasi yang terjadi saat ini yaitu masa pandemi covid 19 yang menyebabkan masyarakat mengalami kesulitan dalam bidang ekonomi sehingga tidak jarang dari beberapa pengguna pintu tersebut harus menggunakan pinjaman tersebut untuk memenuhi kebutuhan hidupnya. ${ }^{2}$ Dan melihat kepada kebutuhan masyarakat yang begitu tinggi terhadap suatu pinjaman keuangan maka tidak menutup kemungkinan untuk para pelaku pinjaman online pinjol ilegal dalam hal ini dapat memiliki celah untuk memasuki ruang tersebut dalam melakukan suatu tindakan dan atau perbuatan yang melawan hukum. Kondisi krisis saat ini dimanfaatkan oleh para pelaku pinjol ilegal dengan menawarkan berbagai macam platform media digital sebagai bentuk penawaran kepada masyarakat untuk dapat menggunakannya yang mana target daripada pelaku ini sendiri ialah masyarakat yang memiliki literasi keuangan rendah dan juga pengetahuan terkait dengan perlindungan hukum terhadap dirinya untuk melakukan suatu tindakan atau perbuatan yang berkaitan dengan penggunaan media elektronik terhadap bidang keuangan. ${ }^{3}$ Yang mana dalam hal ini tidak mengetahui bahwa pinjol tersebut Apakah sudah terdaftar dalam Otoritas Jasa

\footnotetext{
${ }^{1}$ Priliasari, E. (2019). Pentingnya Perlindungan Data Pribadi Dalam Transaksi Pinjaman Online. Majalah Hukum Nasional, 49(2), 1-27., hlm 3

${ }^{2}$ Pardosi, R. O. A. G., \& Primawardani, Y. Perlindungan Hak Pengguna Layanan Pinjaman Online Dalam Perspektif Hak Asasi Manusia (Protection of the Rights of Online Loan Customers from a Human Rights Perspective)., hlm 354

${ }^{3}$ Abdullah, A. (2021). Analisis Pengetahuan Pinjaman Online Pada Masyarakat Surakarta. JESI (Jurnal Ekonomi Syariah Indonesia), 11(2).,hlm 109
} 
Keuangan (OJK) Atau belum terdaftar dikarenakan hal tersebut merupakan suatu hal yang penting untuk diperhatikan agar dapat melihat bahwa penjual tersebut merupakan suatu pinjol yang dapat memiliki pertanggungjawaban dalam pelaksanaan suatu kegiatan di bidang yang dilakukannya atau merupakan suatu pinjol ilegal. ${ }^{4}$

Dan dalam hal ini terkait dengan pelaksanaan dari pinjol ilegal tersebut sangat meresahkan masyarakat dikarenakan beberapa operator dari aplikasi pinjol tersebut memiliki akses terhadap data pribadi yang dimiliki oleh korban sebagai masyarakat untuk Sebagai pengguna aplikasi penjual tersebut sehingga tidak jarang ditemukan beberapa operator dari pinjol tersebut membuat kalor kepada pengguna pinjol tersendiri. Dan bahkan dalam hal ini debt collector Pinjol juga tidak jarang diketahui melakukan suatu intimidasi pada korban untuk dapat segera melakukan pembayaran terhadap hutang yang dilakukan oleh pengguna pinjol tersebut sehingga hal tersebut merupakan suatu bentuk ancaman dan juga perusahaan yang diterima oleh pengguna pinjol tersendiri. ${ }^{5}$ Hal tersebut juga disebabkan oleh ketidaktahuan dan kepahaman dari pengguna pinjol dalam memahami media ataupun aplikasi pinjol yang digunakannya.

Para pelaku pinjol ilegal dalam hal ini dalam memberikan penawaran kepada pengguna pinjol memang sangat menarik yang mana mereka untuk mendapatkan uang yang merupakan kebutuhan dari pengguna pinjol itu sendiri. Pengguna pinjol hanya cukup melakukan verifikasi pendataan akun dan kemudian mengajukan proses pinjaman dana dan dalam segi pencairan dan juga penyelesaian untuk dana tersebut dapat disampaikan kepada pengguna pinjol itu sangat sederhana dan tidak dapat kesulitan dalam melakukan prosesnya. Di Indonesia banyak terjadi di beberapa kasus yang mengakibatkan kerugian oleh masyarakat terkait dengan kasus pinjol ilegal ini sendiri. yang mana Banyak aplikasi pinjol tidak terdaftar ataupun memiliki izin yang diberikan oleh OJK. ${ }^{6}$ dan Meskipun demikian kasus yang banyak tersebut tidak sedikit yang tidak dapat diproses hukum karena dalam hal ini Beberapa kasus terkait dengan pinjol ilegal ini banyak cara yang dilakukan oleh pinjol ilegal untuk melakukan kegiatan yang merugikan masyarakat tersebut yang mana Salah satunya yaitu dalam transaksi yang dilakukan semua tidak merupakan transaksi yang dilakukan secara langsung atau tatap muka melainkan semua transaksi dilakukan secara elektronik dan juga dalam hal ini pengguna pinjol ilegal tersebut tidak mengetahui isi perjanjian yang dilakukan antara pengguna pinjol dan pihak pinjol ilegal itu sendiri sehingga jika terjadi suatu hal yang mungkin dalam isi perjanjian tersebut merugikan pihak pengguna pinjol ilegal tersebut maka dalam segi penegakan hukum akan sulit untuk diselesaikan dan mencari pembelaan terhadap pengguna pinjol yang dirasa merugikan.

Untuk itu diperlukan upaya dari pemerintah dalam rangka pemberantasan masalah pinjol ini. Mengenai perihal tersebut, Peraturan Otoritas Jasa Keuangan (POJK) Nomor 77/POJK.01/2016 tentang Layanan Pinjam Meminjam Uang Berbasis Teknologi Informasi

\footnotetext{
${ }^{4}$ Wahyuni, R. A. E., \& Turisno, B. E. (2019). Praktik Finansial Teknologi Ilegal Dalam Bentuk Pinjaman Online Ditinjau Dari Etika Bisnis. Jurnal Pembangunan Hukum Indonesia, 1(3), 379-391., 389

${ }_{5}^{5}$ Sastradinata, D. N. (2020). Aspek Hukum Lembaga Pinjaman Online Ilegal di Indonesia. Jurnal Independent, 8(1), 293-301., 295

${ }^{6}$ Sidiq, V. A. R. A., \& Setiawan, H. (2022). Analisis Framing Pemberitaan Kasus Pinjaman Online Warga Negara China pada Media Online CNNIndonesia. com dan Nasional Tempo. com. EDUKATIF: JURNAL ILMU PENDIDIKAN, 4(1), 851-861., hlm 853
} 
(LPMUBTI), Undang-Undang Nomor 19 Tahun 2016 tentang perubahan atas Undang-Undang Nomor 11 Tahun 2008 tentang Informasi dan Transaksi Elektronik (UU ITE) dan UndangUndang Nomor 8 Tahun 1999 tentang Perlindungan Konsumen (UUPK), ternyata belum sepenuhnya dapat memberikan jaminan berupa perlindungan hukum bagi para pengguna layanan pinjol.

Mengacu pada uraian persoalan dimana telah dideskripsikan di atas, maka rumusan masalah yang ada ialah bagaimana perlindungan hukum terhadap pengguna jasa pinjol ilegal di Indonesia? dan apa hambatan penegak hukum dalam menangani kasus pinjol di Indonesia?. Tujuan daripada pelaksanaan penelitian ini yakni memberikan informasi kepada masyarakat terkait perlindungan hukum bagi pengguna jasa pinjol illegal di Indonesia dan sanksi pidana yang dapat menjerat pelaku pinjol illegal serta upaya penegak hukum dalam memberantas kasus pinjol illegal diindonesia.

\section{METODE PENELITIAN}

Adapun metode penelitian yang digunakan dalam penelitian ini berupa metode penelitian normatif, yakni dengan melakukan pendekatan peraturan perundang-undangan, maka karena itu sumber jenis data dimana dimanfaatkan ialah jenis data sekunder. Serta teknik pengumpulan data memakai studi pustaka dan metode analisis data yaitu kualitatif

\section{HASIL DAN PEMBAHASAN}

\section{Perlindungan Hukum Bagi Pengguna Jasa Pinjaman Online Ilegal di Indonesia}

Berkaitan dengan melihat kepada kebijakan hukum pidana yang diberikan untuk menjadi suatu perlindungan hukum bagi pengguna jasa pinjol di Indonesia. Dalam hal ini yang merupakan suatu perhatian yang harus dilihat yaitu hak pengguna pinjol yang mana hal tersebut merupakan suatu aspek yang perlu untuk diperhatikan dalam suatu transaksi pinjol ilegal di Indonesia. Dan hal tersebut tentunya untuk para penyelenggara pinjol agar tidak lupa dengan hak-hak yang seharusnya dimiliki oleh pengguna layanan pinjol yang mana pengguna lain pinjol itu sendiri dalam hal ini memiliki kedudukan sebagai konsumen. POJK Nomor 77 /POJK.01/2016 tentang LPMUBTI Dalam hal ini memang mengatur terkait dengan penggunaan jasa pinjol di Indonesia namun dalam hal ini ada pengaturan tersebut tidak dijelaskan secara khusus mengenai hak yang kemudian dimiliki oleh pengguna jasa pinjol melainkan dalam Ketentuan tersebut hanya mengatur yang berkaitan dengan kewajiban dan juga apa yang menjadi larangan dalam pelaksanaan penyelenggaraan tinggal di Indonesia. ${ }^{7}$ Dan dalam hal ini beberapa Apa hak yang sudah seharusnya dimiliki oleh pengguna ginjal yaitu itu Sudah Selayaknya pengguna pinjol memiliki hak atas informasi terkait dengan layanan yang diberikan oleh pinjol berbasis informasi teknologi, Kemudian pengguna jasa pinjol juga memiliki hak terkait dengan informasi yang berkaitan dengan penerimaan, penundaan, dan juga penolakan terhadap permohonan yang di ajukan oleh pengguna pinjol. Dan juga pengguna pinjol memiliki hak untuk

${ }^{7}$ Disemadi, H. S., \& Regent, R. (2021). Urgensi Suatu Regulasi yang Komprehensif Tentang Fintech Berbasis Pinjaman Online Sebagai Upaya Perlindungan Konsumen di Indonesia. Jurnal Komunikasi Hukum (JKH), 7(2), 605-618., hlm 608 
mendapatkan segala informasi terkait dengan dokumen dalam transaksi elektronik berkaitan dengan hal tersebut yang mudah dimengerti dan dibaca dan menggunakan bahasa Indonesia yang baik dan benar.

Kemudian dalam hal ini bahasa Indonesia sangat diperlukan untuk pengguna pinjol agar dapat dengan mudah memahami apa yang menjadi di maksud dan tujuan dari suatu dokumen ataupun setiap transaksi yang dilakukan dalam melakukan transaksi di pinjol tersebut. Dan juga dalam hal ini pengguna pinjol memiliki hak atas perlindungan dari segala upaya pengalihan tanggung jawab dan atau kewajiban terhadap penyelenggaraan yang dilakukan oleh pengguna pinjol tersebut. ${ }^{8}$ Dan yang tentunya sudah ada pada pengguna pinjol yaitu perlindungan yang mana dalam hal ini merupakan suatu keharusan dan kewajiban dalam penyelenggaraan benjol di Indonesia yang tunduk pada peraturan perundang-undangan yang berlaku.

Pada pasal 4 UUPK Dalam hal ini telah mengatur terkait dengan hak yang dimiliki oleh pengguna pinjol di Indonesia dimana hak tersebut telah diatur dalam Ketentuan tersebut bahwa meliputi hak atas kenyamanan, keamanan dan keselamatan dalam menggunakan suatu jasa pinjol di Indonesia. Pada Ketentuan tersebut tentunya pengguna pinjol dalam hal ini memiliki kedudukan sebagai konsumen yang mana diatur dalam Ketentuan tersebut oleh karena itu pengguna pinjol memiliki perlindungan terkait dengan transaksi yang dilakukan dengan pinjol ilegal jika melakukan suatu perbuatan yang dilarang dalam Ketentuan tersebut . Dan juga hak yang yang terdapat pada pasal tersebut yaitu hak untuk dapat memilih barang dan atau jasa sesuai dengan nilai tukar dengan kondisi serta jaminan yang menjanjikan, Dan hak atas suatu informasi yang benar, Jelas dan jujur. Dan hak lainnya yaitu pengguna jasa pinjol dalam hal ini memiliki hak untuk didengar pendapat dan keluhannya oleh penyedia layanan pinjol. Dan juga dalam hal ini pengguna penjual dalam segi perlindungan hukum memiliki hak untuk dapat perlindungan terkait dengan upaya penyelesaian sengketa dalam perlindungan konsumen yang dalam hal ini dapat dilakukan secara patut. Dan juga terdapat hak untuk dapat dilakukan oleh penyelenggara pinjol kepada pengguna pinjol yaitu pengguna pinjol dalam hal ini memiliki hak untuk dapat Diberikan layanan yang baik dan juga tidak secara diskriminatif serta pengguna pinjol dalam hal ini akan mendapatkan ganti rugi terhadap suatu kerugian yang diterimanya. Kemudian akad yang diatur dalam ketentuan peraturan perundang-undang lainnya yang tidak disebutkan dalam Ketentuan tersebut.

Dan jika melihat kepada Ketentuan tersebut di atas maka dalam hal ini pengguna penjual tentunya sebagai konsumen memiliki hak yang harus diperhatikan oleh suatu perusahaan pinjol dalam melakukan suatu transaksi di Indonesia. Namun dalam pelaksanaannya dalam hal ini penyelenggara pelayanan pinjol melakukan suatu perbuatan yang bertentangan dengan peraturan yang berlaku Sehingga dalam hal ini sangat merugikan pihak pengguna pinjol. Dan tidak jarang hak dari pengguna pinjol dalam hal ini diabaikan oleh perusahaan tinggal sebagai penyedia layanan pinjol. Beberapa pelaksanaan yang tidak dilakukan oleh layanan pinjol terhadap pengguna pinjol dalam hal ini yaitu perlakuan secara baik yang seharusnya diberikan oleh

${ }^{8}$ Wibowo, S. A., \& Sumiyati, Y. (2021). Tanggung Jawab Korporasi Fintech Lending Ilegal Dalam Perspektif Perlindungan Konsumen [Corporate Liability of Illegal Fintech Lending in the Perspective of Consumer Protection Law]. Law Review, 117-144., hlm 120 
layanan pinjol kepada pengguna pinjol namun justru sebaliknya layanan penjual dalam hal ini melakukan pinjol dengan secara tidak baik yaitu dalam pelaksanaannya terdapat suatu ancaman dan atau teror dari pihak penagih layanan pinjol kepada pengguna pinjol serta cara yang digunakan oleh layanan pinjol tersebut kepada pembeli penjual dalam hal ini yaitu dengan mengirimkan gambar dan atau tulisan kepada pihak yang dikenal baik oleh pengguna tinggal sehingga hal tersebut memberikan suatu ancaman kepada pengguna pinjol yang diberikan oleh layanan pinjol untuk menagih dana kepada pengguna pinjol. Jika melihat kepada kasus tersebut dalam pelaksanaannya maka Hal tersebut tentunya telah melanggar ketentuan yang berlaku yakni pada pasal 29 ayat 1 dan Pasal 30 Undang-Undang Nomor 39 Tahun 1999 tentang Hak Asasi Manusia (UU HAM) Dan juga ketentuan yang terdapat pada pasal 4 UUPK.

Dalam hal ini kondisi yang sangat merugikan yang diterima oleh pengguna pinjol di Indonesia tentu sangat meresahkan dan mengganggu keamanan seseorang. Ketentuan yang berlaku di dalam KUHP dan uu ite adalah karena belum dapat memenuhi aspek perlindungan terkait dengan kepentingan dari hak yang dimiliki oleh pengguna pinjol di Indonesia.Yang mana dalam hal ini ketentuan pidana dalam pengaturan tersebut tidak secara seluruhnya menjangkau suatu tindak pidana dalam penyelenggaraan pinjol yang terjadi di Indonesia. Dalam melakukan penegakan hukum dalam hal ini pelaku Pinjol ilegal dalam merugikan pengguna ginjal dijerat menggunakan tindak pidana yang juga Hanya berupa penyebaran data pribadi, pengancaman, penagihan, penipuan, pencemaran nama baik, dan pekerjaan seksual yang dilakukan melalui media elektronik. Dan juga dalam hal ini terkait dengan suatu kasus yang dialami oleh pengguna pinjol ilegal di Indonesia kejahatan yang dilakukan kan oleh pelaku pinjol ilegal tersebut merupakan delik aduan. Sebagaimana yang diketahui bahwa dari batuan merupakan suatu delik yang berupa penuntutan Yang dapat dilakukan hanya jika pihak yang dirugikan dalam hal ini melakukan pengaduan kepada kepolisian untuk dilakukannya suatu penegakan hukum dan pengaduan tersebut dilakukan oleh pihak yang terkena (gelaedeede parti). Dalam hal ini dari aduan dibedakan menurut sifatnya yang mana delik aduan yang pertama yaitu delik aduan Absolut di mana contoh dari teori tersebut yaitu terdapat dalam Pasal 284, 310, 332 KUHP. Yang mana delik pada Ketentuan tersebut sifatnya hanya dapat dilakukan berdasarkan suatu pengaduan. Kemudian detik selanjutnya yang dibedakan menurut sifatnya yaitu delik aduan yang bersifat relatif yang dalam hal ini contohnya terdapat pada pasal 367 KUHP tentang Pencurian. Dalam hal ini disebut relatif karena dalam delik Ini adanya suatu hubungan istimewa antara si pelaku dengan korban. Sehingga berdasarkan hal tersebut terkait dengan kasus yang terjadi oleh pengguna pinjol di Indonesia tidak sedikit yang tidak dapat diproses hukum dikarenakan pengaduan yang dilakukan oleh pengguna pinjol yang di dirikan oleh layanan pinjol di Indonesia tidak melakukan pengaduan atas suatu pelanggaran hak yang kemudian diterimanya.

Perlindungan terhadap hak Pengguna pinjol yang harus dijamin oleh pemerintah Hal ini merupakan suatu perhatian khusus yang perlu diperhatikan sehingga pemerintah dalam hal ini dapat memberikan suatu perlindungan melalui suatu pengaturan perundang-undangan yang secara khusus mengatur terkait dengan kasus pelanggaran hak Pengguna layanan pinjam di Indonesia . Yang mana tidak jarang dari pelanggaran hak Injil tersebut mengarah kepada suatu 
perbuatan melawan hukum yang mengakibatkan kerugian baik secara material maupun immaterial yang di alami oleh korban. Dan dengan adanya suatu ancaman dan ataupun teror hal tersebut merupakan suatu kelalaian dalam melakukan pembayaran yang dianggap oleh layanan pinjol merupakan suatu kesalahan dari pengguna pinjol tanpa harus memperhatikan hak yang kemudian melekat pada pengguna pinjol dan harus diberikan perlindungan. Salah satu pengguna pinjol dalam hal ini yang telah terlanggar oleh layanan pinjol yaitu berupa ancaman dan teror yang diberikan oleh pihak perusahaan pinjol maka dalam hal ini hal tersebut memerlukan suatu perlindungan hukum karena pengguna pinjol dalam hal ini dapat mengalami kerugian yaitu itu rasa takut, rasa malu serta tidak nyaman akibat dari ancaman dan juga teror yang dilakukan oleh layanan pinjol terhadapnya. Tidak hanya itu dan ini ini jika dikaitkan dengan kasus tersebut maka pada pasal 19 ayat 2 UU HAM. Kelalaian ataupun ketidakmampuan seseorang pengguna pinjol dalam melakukan pembayaran tidak dapat dijadikan suatu alasan untuk layanan pinjol melakukan pemidanaan kepada pengguna ginjal tersebut. Dan dalam pelaksanaannya tidak jarang layanan pinjol memberikan ancaman yaitu akan melakukan pelaporan kepada pengguna pinjol dalam hal kelalaian melakukan pembayaran. Dan juga dalam hal ini terkait dengan penegakan hukum penegak hukum dalam hal ini memiliki kesulitan terhadap permasalahan tersebut karena penggunaan pinjol dalam hal ini berkedudukan sebagai debitur dengan layanan pinjol yang lagi memiliki kedudukan sebagai kreditor yang mana hal tersebut merupakan kategori dalam suatu perjanjian hutang piutang yang mana hal tersebut harus diselesaikan secara perdata dan tidak melalui bidang pidana oleh karena itu Jika aparat hukum tetap memberikan sanksi pidana kepada pihak tersebut maka perbuatan tersebut merupakan suatu pelanggaran terhadap peraturan perundang-undangan yang berlaku. ${ }^{9}$

POJK No.77/POJK.01/2016 tentang LPMUBTI Pada pasal 29 yang dalam hal ini telah mewajibkan layanan pinjol untuk dapat menerapkan prinsip yang diberikan untuk perlindungan pengguna tinggal tersebut yaitu antara lain berupa transparansi, perlakuan yang adil dan tidak diskriminatif, kerahasiaan dan juga jaminan terhadap keamanan data dan penyelesaian sengketa yang dapat dilakukan secara cepat sederhana dan biaya terjangkau.

Untuk itu, pelaku bisnis yang menyalahgunakan hak pengguna sebagai konsumen dapat dikenakan sanksi. Pada dasarnya hubungan antara pelanggan dan pelaku usaha merupakan hubungan peraturan keperdataan, namun UUPK juga berlaku dalam pidana bagi pelanggar kebebasan konsumen, sebagaimana tertuang dalam UUPK Pasal 45 Ayat 3, "Penyelesaian di luar pengadilan sebagaimana dimaksud pada Ayat 2 tidak menghilangkan tanggung jawab pidana sebagaimana diatur dalam undang-undang." Beberapa kasus terkait dengan yang dialami oleh pengguna pinjol dalam hal ini berawal dari suatu perjanjian pinjaman yang diduga dilakukan oleh layanan pinjol dibuat secara sepihak dan tidak dipahami oleh pihak konsumen yaitu pengguna layanan pinjol yang mana hal tersebut tentunya berkaitan dengan isi perjanjian tidak diketahui oleh calon pengguna pinjol. Dari aspek hukum, ada larangan bagi penyelenggara

\footnotetext{
${ }^{9}$ Sundari, S. (2021). TINDAKAN HUKUM ATAS KASUS HUTANG PADA PINJAMAN ONLINE ILEGAL. Lex Librum: Jurnal Ilmu Hukum, 7(2), 243-250., 245
} 
pinjol sebagai pelaku usaha untuk mencantum ketentuan standar untuk setiap arsip dan perjanjian sebagaimana dinyatakan dalam Pasal 18 Ayat (1) UUPK, bilamana:

1. Menyatakan pengalihan tanggung jawab pelaku usaha;

2. Menyatakan bahwa pelaku usaha berhak menolak penyerahan kembali barang yang dibeli konsumen;

3. Menyatakan bahwa pelaku usaha berhak menolak penyerahan kembali uang yang dibayarkan atas barang dan/atau jasa yang dibeli oleh konsumen;

4. Menyatakan pemberian kuasa dari konsumen kepada pelaku usaha baik secara langsung maupun tidak langsung untuk melakukan segala tindakan sepihak yang berkaitan dengan barang yang dibeli oleh konsumen secara angsuran;

5. Mengatur perihal pembuktian atas hilangnya kegunaan barang atau pemanfaatan jasa yang dibeli ileh konsumen;

6. Memberi hak kepada pelaku usaha untuk mengurangi manfaat jasa atau mengurangi harta kekayaan konsumen yang menjdi obyek jual beli jasa;

7. Menyatakan tunduknya konsumen kepada peraturan yang berupa aturan baru, tambahan, lanjutan dan/atau pengubahan lanjutan yang dibuat sepihak oleh pelaku usaha dalam masa konsumen memanfaatkan jasa yang dibelinya;

8. Menyatakan bahwa konsumen memberi kuasa kepada pelaku usaha untuk pembebanan hak tanggungan, hak gadai, atau hak jaminan terhadap barang yang dibeli oleh konsumen secara angsuran.

Lebih lanjut dalam Pasal 18 Ayat 2 UUPK dikemukakan bahwa Dalam hal ini pelaku usaha sebagai mana yang diatur dalam Ketentuan tersebut dilarang untuk memberikan klausula baku yang dalam hal ini dalam bentuknya terdapat suatu kesulitan untuk dipahami secara jelas maksud dan tujuannya. Dan dalam hal ini maksud dari Ketentuan tersebut berupaya untuk memberikan perlindungan serta kemudahan Agar suatu standar kontrak dapat dengan mudah dipahami dan diberlakukan dan kepada pelaku usaha agar Mencegah suatu kerugian yang dapat diterima oleh konsumen. sehingga pada tahap law enforcement Akan mudah bagi penegak hukum ataupun para pihak untuk dapat menyelesaikan suatu permasalahan yang timbul terhadap perjanjian tersebut yang mana hal tersebut juga melihat kepada prinsip asas kebebasan berkontrak yang diatur dalam peraturan perundang-undangan yang berlaku.

Dalam UU ITE juga memiliki kebijakan sebagai upaya perlindungan hukum pengguna layanan pinjol yang mana terdapat pada Pasal 26 Ayat 1 dan 2 dimana dalam pasal 1 terkait dengan penggunaan data pribadi seseorang dalam penggunaannya harus berdasarkan persetujuan pihak yang berkepentingan terhadap data tersebut dan pada pasal 2 menegaskan pelanggaran yang dilakukan pada ayat 1 maka pihak yang dirugikan dapat mengajukan gugatan terhadap kerugian yang diterimanya atas perbuatan yang dimaksud pada ayat 1 tersebut. Kemudian pada Pasal 45 Ayat 3 UU ITE yang mana dalam pasal ini berkaitan dengan perlindungan pengguna layanan pinjol dalam hal ini pelaku memenuhi unsur dalam pasal ini yang mana telah tanpa hak dan disengaja mendistribusikan data milik pengguna yang mana perbuatan tersebut juga termasuk dalam pasal 27 ayat 3 . 
Kemudian tidak sampai disitu berkaitan dengan ancaman yang kerap dilakukan oleh debt collector kepada pengguna jasa pinjol telah memiliki perlindungan hukum yang melindunginya yaitu terdapat pada pasal 45 huruf B UU ITE yang mana dalam pasal ini melindungi pengguna jasa pinjol jika terjadi ancaman yang kemudian diterimanya yang bertujuan untuk menakutnakuti dan maksud ini juga merupakan maksud dari pasal 29 UU ITE yang memuat perlindungan terhadap ancaman dari layanan jasa pinjol tersebut. Dengan eksistensi aturan terkait, penyelesaian secara hukum dapat dilakukan melalui pengaturan peraturan pidana terhadap pelanggaran hak-hak istimewa pengguna layanan yang hanya memberikan keuntungan sepihak kepada organisasi pinjol. Meskipun demikian, untuk penggunaan informasi pribadi seseorang, masih diperlukan pedoman lebih lanjut, yang hingga saat ini belum ada pedoman yang secara eksplisit mengatur hal ini. ${ }^{10}$ Untuk situasi ini, sangat dikecewakan memikirkan bahwa asuransi informasi juga merupakan hak yang harus mendapatkan perlindungan hukum. Di seluruh dunia, jaminan informasi telah dianggap sebagai sesuatu yang mapan sebagai "habeas data" khususnya hak individu untuk mendapatkan keamanan atas informasinya dan untuk pertahanan ketika ditemukan kesalahan dalam informasinya. Meski demikian, kebenaran keamanan informasi di Indonesia memang berbanding terbalik dengan ius constitutum yang diberlakukan. Dalam hal ini perlunya persyaratan untuk lembaga pengawas jaminan informasi individu atau Otoritas Proteksi Data yang tugasnya adalah untuk menjamin bahwa semua standar keamanan informasi pribadi dapat dipenuhi.

Dalam hal ini menimbang kepentingan dari pengaturan yang seharusnya dibentuk terkait dengan perlindungan data pribadi maka pemerintah dalam hal ini Sangat perlu untuk membentuk suatu undang-undang terkait dengan perlindungan data pribadi yang mana melihat pada kasus pinjol yang terjadi sehingga pengaturan terhadap data pribadi tersebut sangat dapat berguna untuk diterapkan dalam permasalahan kasus tersebut dan juga dalam hal ini diharapkan dengan adanya pengaturan tersebut dapat memberikan suatu kepastian dan menciptakan suatu ketertiban terkait dengan permasalahan hukum yang ada di tengah masyarakat. Dan juga pengaturan tersebut bertujuan untuk agar suatu data pribadi yang diberikan oleh seseorang tidak disalahgunakan untuk kepentingan yang merugikan pihak tersebut. ${ }^{11}$

Terlepas dari berbagai peraturan dan pedoman yang memberlakukan sanksi terhadap penyelenggara yang menyalahgunakan hak pengguna layanan pinjol, penting bagi pemerintah untuk menemukan cara dalam mencegah dan menangani berbagai kasus pelanggar hukum yang diajukan oleh penyelenggara pinjol, salah satunya melalui upaya sosialisasi yang diselenggarakan OJK sebagai tim dengan Kementerian Komunikasi dan Informatika (KOMINFO) untuk memberikan informasi kepada masyarakat luas tentang kemajuan dari berbagai sudut, baik keabsahan, biaya pembiayaan, strategi penawaran, dan lainnya. Selain itu, juga penting untuk melakukan penyuluhan kepada masyarakat demi mengarahkan atau membantu mereka dalam mengetahui akibat dari penggunaan pinjol dengan disertai kasus-kasus

\footnotetext{
${ }^{10}$ Olifiansyah, M. (2021). Perlindungan Hukum Pencurian Data Pribadi dan Bahaya Penggunaan Aplikasi Pinjaman Online. Jurnal Hukum De Rechtsstaat, 7(2), 199-205., hlm 202

11 Elsa, A. E. F. (2021). Dilema Pinjaman Online di Indonesia: Tinjauan Sosiologi Hukum dan Hukum Syariah. DIKTUM: Jurnal Syariah dan Hukum, 19(2), 109-119., hlm 110
} 
yang pernah terjadi sehubungan dengan usaha yang mengarah pada akibat hukum ketika pengguna tidak melakukan cicilan. Untuk situasi ini, penting untuk mengungkapkan upaya yang harus dilakukan oleh daerah dengan asumsi hak-hak mereka dilanggar, terutama tentang informasi pribadi mereka sendiri.

Usaha selain dari itu adalah bilamana terang organisasi yang memiliki layanan terkomputerisasi itu belum memiliki izin dari OJK, juga dikenal sebagai terlarang, maka saat itu juga, tidak ada cara lain selain memanfaatkan teknik yang represif dengan aksi penutupan layanan suatu aplikasi terkait. ${ }^{12}$ Dengan demikian, koordinasi antara OJK dan KOMINFO memiliki relevansi. Selain itu, KOMINFO juga harus memiliki kemampuan kerangka kerja mekanis dengan mengabaikan metode yang terkait dengan pengenalan aplikasi pada layanan terkomputerisasi jika tidak memenuhi persyaratan yang sesuai seperti yang ditentukan dalam peraturan. Dalam situasi khusus ini, perusahaan penyedia inovasi teknologi finansial diharapkan untuk memasukkan catatan sebagai legalitas organisasi dari OJK sebelum memperkenalkan aplikasi pada tahap lanjutan, yakni platform digital.

Terkait dengan framework tersebut, diyakini juga akan ada kemampuan untuk mengidentifikasi dan selanjutnya melakukan tindakan preventif terhadap tahapan atau aplikasi yang telah dinonaktifkan oleh regulator, untuk situasi ini OJK, namun telah berubah dengan membentuk aplikasi baru disertai dengan pembentukan identitas yang baru. Salah satu praktik tersebut telah menyebabkan meluasnya pinjol ilegal di tengah-tengah masyarakat. Pemerintah memiliki pilihan yang cukup signifikan di antara pilihan-pilihan ini, salah satunya adalah memikirkan pentingnya pengendalian administrasi Financial Technology (Fintech), pemerintah juga harus membuat aturan khusus sebagai aturan yang mengarahkan berbagai fintech termasuk layanan awal atau crownfunding yang juga mencakup beban persetujuan sanksi hukum terhadap penyedia jasa layanan yang menggunakan entitas ilegal. Hal ini dipandang penting sebagai payung hukum bagi penegak hukum untuk bertindak melawan maraknya pinjol ilegal.

Dalam hal ini Jika layanan pinjol memiliki legalitas perusahaan yang menjelaskan terdaftar maka perlindungan terhadap pengguna layanan pinjol dalam hal ini dapat dipastikan suatu penegakan hukumnya karena jika suatu layanan penjual tidak terdaftar dan tidak memiliki legalitas dalam menjalankan usahanya maka hal tersebut sangat sulit untuk menjangkau terkait dengan penegakan hukum yang dilakukan oleh layanan penjual tersebut yang mana jika melihat kepada kasus yang telah terjadi dalam hal ini sulit untuk menjangkau penegakan hukum dikarenakan legalitas dari layanan pinjam itu sendiri Tidak memiliki suatu kepastian hukum yang dapat dilakukan suatu penegakan hukum terkait dengan pelaksanaannya.. Untuk situasi ini, penyelenggara diwajibkan untuk memberikan escrow account dan virtual account, untuk mengganti pelunasan pinjaman, peminjam tidak membayar langsung ke pemberi pinjaman namun melalui kerangka dan saluran yang telah diberi dan disediakan oleh penyelenggara, yakni melalui escrow account yang telah diberikan untuk selanjutnya dikirim ke virtual account pemberi pinjaman. Tujuan daripada penyediaan escrow account dan virtual account tersebut

\footnotetext{
${ }^{12}$ Simangungsong, M. (2020). PENGAWASAN OTORITAS JASA KEUAGAN TERHADAP SIMPAN PINJAM ONLINE (FINTECH). Jurnal Hukum PATIK, 9(3), 147-159., hlm 148
} 
ialah agar penyedia pinjaman fintech peer to peer lending tidak menyalahgunakan dana pinjaman yang diberikan pihak peminjam, dimana dikatakan juga bahwa aturan pengelolaan kerangka layanan ini telah sesuai dengan ketentuan pengarahan dari OJK dimana tertuang dalam Pasal 26 POJK No.77/POJK.01/2016 Tentang LPMUBTI.

Hambatan penegak hukum dalam menangani kasus pinjol di Indonesia.

Rasa resah dari publik harus diakhiri seiring dengan banyak kasus terkait dengan pinjol ilegal. Kewajiban negara adalah melindungi penduduk sesuai perintah UUPK. Negara harus membuat kerangka perlindungan pembeli yang berisi komponen jaminan yang sah dan pengungkapan data bersama dengan akses ke data. Lebih lanjut, Tumalun juga mengungkapkan faktor penghambat dalam mengatasi kejahatan PC dan juga sistem elektronik, khususnya:

1. Staf Ahli yang terbatas. Jumlah tenaga kerja master yang ditetapkan di Indonesia dan China berbeda sangat jauh. Ironisnya ialah bahwa laporan persentase kejahatan digital di Indonesia berkembang, dengan terbatasnya personil dan staf ahli di pihak kepolisian Indonesia, maka pemberantasan kasus-kasus ini tidak dapat diselesaikan dengan cepat. Hasilnya dirasakan langsung oleh orang yang bersangkutan sebagai korban. Kualitas fasilitas teknologi data di Indonesia tidak diragukan lagi sangat bagus, tetapi hampir tidak identik dengan keamanan yang dijamin oleh tiap pengguna.

2. Manajemen pemerintahan yang lemah. Tidak adanya pengawasan atas penggunaan web dapat membuka pintu bagi terjadinya kesalahan atau kejahatan digital. Karena kesalahan menggunakan inovasi terjadi dengan asumsi bahwa ada akses web yang memadai. Saat ini, fasilitas web di berbagai komunitas perkotaan besar di Indonesia sudah cukup memuaskan, baik dari segi kecepatan akses maupun kemudahan pendirian organisasi akses web. Meskipun demikian, tanpa jejak strategi dan perkiraan pencegahan yang merupakan variabel utama, pengguna tanpa syarat dapat memperoleh informasi spesifik yang dapat disalahgunakan oleh pengguna yang tidak bertanggung jawab.

3. Hambatan Prosedural UU ITE Lemahnya instrumen hukum UU ITE terlihat jelas dalam Pasal 27 dan Pasal 37 tentang perbuatan yang diharamkan dimana banyak aparat kepolisian sendiri yang tidak memahami pentingnya pasal tersebut.

Satgas Waspada Investasi (SWI) OJK menghentikan sementara aktivitas sekitar 3.365 pinjol ilegal hingga Juli 2021. Angka tersebut merupakan konsekuensi dari pencarian 7.128 pengaduan terkait pinjol ilegal. Pengurus Dewan Komisioner OJK, Wimboh Santoso, dalam wawancara publik secara virtual terkait penandatangan Surat Pernyataan Bersama tentang pemberantasan pinjol ilegal, menggarisbawahi bahwa semua insan SWI harus menyusun kerangka kerja yang terkoordinasi dan terorganisir untuk melawan kejahatan besar yang melanggar hukum, pinjol ilegal. Pinjol ilegal harus diberantaskan dengan alasan bahwa pelakunya membebani dan bahkan merugikan masyarakat.

Untuk mencegah berkembangnya pinjol ilegal, OJK hingga saat ini telah melakukan berbagai strategi, misalnya program edukasi bagi masyarakat umum untuk memutuskan menggunakan fintech lending yang terdaftar atau disahkan di OJK dan tidak memanfaatkan 
pinjol ilegal. OJK juga menyukai upaya individu SWI lainnya, khususnya melalui pembuatan patrol siber, menghalangi situs dan aplikasi pinjol ilegal, mengendalikan dana cadangan dan memajukan koperasi yang mengajukan pinjol ilegal, melarang payment gateway, serta menangani peraturan hukum pinjol ilegal. OJK juga mendapat reaksi positif dari Google terkait rincian aplikasi kredit individu yang sering disalahgunakan pinjol ilegal. Sejak 28 Juli 2021, Google telah menambahkan prasyarat kualifikasi tambahan untuk aplikasi yang layak bagi pinjaman individu, termasuk lisensi atau kata lainnya yakni terdaftar di OJK).

Untuk sementara, Polri menjamin pencarian para pinjol ilegal di Indonesia dan para penyokong dana asing akan dilanjutkan. Kasubdit Industri Keuangan Non-Bank (IKNB) Direktorat Tindak Pidana Ekonomi Khusus Bareskrim Polri Kombes Ma'mun mengatakan pihaknya telah menangkap 11 tersangka dari dalam negeri. Sedangkan pelaku dari luar negeri belum ditemukan. Pemeriksa melacak banyak elemen pinjol ilegal dengan pendukung keuangan yang berupa warga asing (luar negeri). Selain itu, server dimana mereka gunakan untuk aplikasi juga diketahui berasal dari luar negeri. Untuk itu, Bareskrim Polri menyebut bantuan Direktorat Jenderal Imigrasi Kementerian Hukum dan HAM untuk mengejar para pelaku yang menyelundup ke luar negeri. Alat tersebut tetap dicadangkan untuk menangkap para pelaku dengan asumsi mereka ditemukan telah memasuki wilayah Indonesia.

Jika pemeriksa menggunakan UU ITE, Pasal 27 ayat (4) tentang pemerasan atau potensi bahaya dapat dipaksakan dengan pidana kurungan paling lama 6 (enam) tahun dan ditambah denda paling banyak Rp. 1.000.000.000,00 (satu miliar rupiah) atau Pasal 29 tentang bahaya kebiadaban atau teror yang dititikberatkan secara personal dengan pidana kurungan paling lama 4 (empat) tahun dan denda paling banyak Rp. 750.000.000,00 (tujuh ratus lima puluh juta rupiah). Selanjutnya, pelaku pinjol ilegal yang melakukan penyebaran informasi individu dapat dijerat dengan Pasal 32 ayat (1) UU ITE, dengan hukuman paling berat 8 (delapan) tahun dan denda paling banyak Rp. 2.000.000.000 (dua miliar rupiah). Sedangkan terkait dengan KUHP, pelakunya dapat diancam dengan Pasal 368 tentang pemerasan dengan kurungan paling lama 9 (sembilan) bulan atau Pasal 378 KUHP tentang penipuan atau penyesatan dengan ancaman penahanan 4 (empat) tahun. Namun, yang sebenarnya terjadi ialah beberapa pelaku pinjol ilegal telah dijerat dengan hukum sebagaimana informasi dari Kepolisian yang baru-baru ini disebutkan.

\section{KESIMPULAN}

Berkaitan dengan kebijakan hukum pidana terhadap perlindungan hukum bagi pengguna jasa pinjol ilegal di Indonesia dalam hal ini sudah sangat sering terjadi dan telah banyak merugikan banyak korban dari pengguna pinjol itu sendiri, dan dalam hal ini kebijakan hukum pidana belum secara spesifik dapat mengatur terkait dengan pelaku pinjol ilegal tersebut karena dalam hal ini perjanjian yang dibuat antara pelaku pinjol dan pengguna pinjol adalah dalam bentuk perjanjian yang kemudian dapat diselesaikan dalam perkara perdata. Dan dikarenakan belum ada aturan yang secara khusus mengatur terkait dengan kasus pinjol yang terjadi yang 
berkaitan dengan data pribadi, maka ditinjau dari pelaksanaannya dapat digunakan beberapa peraturan perundangan yang berlaku untuk menyelesaikan permasalahan tersebut.

Diantaranya kebijakan hukum pidana yang dapat digunakan ialah dengan menggunakan pengaturan yang secara jelas dan nyata diterangkan dalam UUPK karena kedudukan dari pengguna pinjol ialah sebagai konsumen maka segala aturan yang mengatur berkaitan dengan perlindungan konsumen pada aplikasi pinjol dapat diterapkan dalam pengaturan ini. Dan juga tidak sampai disitu melihat kepada prakteknya pelaku pinjol ilegal juga memakai perangkat elektronik dalam melakukan perbuatan melawan hukum maka kebijakan hukum pidana yang digunakan dapat dipergunakan UU ITE dalam menerapkan kebijakan pidana untuk memberikan perlindungan bagi pengguna jasa pinjol ilegal.

Kemudian daripada itu hambatan dari penegak hukum dalam melakukan penyelesaian kasus pinjol ilegal di Indonesia ialah karena beberapa faktor yaitu kurangnya tenaga ahli dalam melakukan pencarian bukti fakta dalam kasus pinjol ilegal, lemahnya pengawasan pemerintah yang dalam hal ini bertujuan untuk mengawasi segala aktifitas transaksi elektronik di Indonesia, dan lemahnya perangkat hukum yang digunakan untuk menegakan kebijakan hukum pidana kepada pelaku. Dan juga korban memiliki keterbatasan pengetahuan terhadap penyelesaian kasus pinjol ilegal yang dalam hal ini kerap memberikan ancaman yang mana penegak hukum membutuhkan aduan atau pelaporan untuk melanjutkan proses hukum dan disisi lain delik ini merupakan delik aduan.

\section{DAFTAR PUSTAKA}

Abdullah, A. (2021). Analisis Pengetahuan Pinjaman Online Pada Masyarakat Surakarta. JESI (Jurnal Ekonomi Syariah Indonesia), 11(2).

Disemadi, H. S., \& Regent, R. (2021). Urgensi Suatu Regulasi yang Komprehensif Tentang Fintech Berbasis Pinjaman Online Sebagai Upaya Perlindungan Konsumen di Indonesia. Jurnal Komunikasi Hukum (JKH), 7(2), 605-618.

Elsa, A. E. F. (2021). Dilema Pinjaman Online di Indonesia: Tinjauan Sosiologi Hukum dan Hukum Syariah. DIKTUM: Jurnal Syariah dan Hukum, 19(2), 109-119

Nurhayati, M., Indriani, I., \& Junaenah, M. (2021). Sosialisasi Pentingnya Kesadaran Hukum Terhadap Pinjaman Online. ADIBRATA Jurnal, 2(1).

Olifiansyah, M. (2021). Perlindungan Hukum Pencurian Data Pribadi dan Bahaya Penggunaan Aplikasi Pinjaman Online. Jurnal Hukum De Rechtsstaat, 7(2), 199-205.

Pardosi, R. O. A. G., \& Primawardani, Y. Perlindungan Hak Pengguna Layanan Pinjaman Online Dalam Perspektif Hak Asasi Manusia (Protection of the Rights of Online Loan Customers from a Human Rights Perspective).

Priliasari, E. (2019). Pentingnya Perlindungan Data Pribadi Dalam Transaksi Pinjaman Online. Majalah Hukum Nasional, 49(2), 1-27

Poernomo, S. L. Perlindungan Hukum Konsumen Terhadap Praktik Teknologi Finansial Ilegal Dalam Bentuk Pinjaman Online Ilegal 
Sastradinata, D. N. (2020). Aspek Hukum Lembaga Pinjaman Online Ilegal di Indonesia. Jurnal Independent, 8(1), 293-301.

Sidiq, V. A. R. A., \& Setiawan, H. (2022). Analisis Framing Pemberitaan Kasus Pinjaman Online Warga Negara China pada Media Online CNNIndonesia. com dan Nasional Tempo. com. EDUKATIF: JURNAL ILMU PENDIDIKAN, 4(1), 851-861.

Sundari, S. (2021). TINDAKAN HUKUM ATAS KASUS HUTANG PADA PINJAMAN ONLINE ILEGAL. Lex Librum: Jurnal Ilmu Hukum, 7(2), 243-250

Simangungsong, M. (2020). PENGAWASAN OTORITAS JASA KEUAGAN TERHADAP SIMPAN PINJAM ONLINE (FINTECH). Jurnal Hukum PATIK, 9(3), 147-159

Sugangga, R., \& Sentoso, E. H. (2020). Perlindungan Hukum Terhadap

Wahyuni, R. A. E., \& Turisno, B. E. (2019). Praktik Finansial Teknologi Ilegal Dalam Bentuk Pinjaman Online Ditinjau Dari Etika Bisnis. Jurnal Pembangunan Hukum Indonesia, 1(3), 379-391., Wibowo, S. A., \& Sumiyati, Y. (2021). Tanggung Jawab Korporasi Fintech Lending Ilegal Dalam Perspektif Perlindungan Konsumen [Corporate Liability of Illegal Fintech Lending in the Perspective of Consumer Protection Law]. Law Review, 117-144.

Pengguna Pinjaman Online (Pinjol) Ilegal. Pakuan Justice Journal Of Law, 1(1), 47-61.

Kitab Undang-Undang Hukum Pidana

Peraturan Otoritas Jasa Keuangan (POJK) Nomor 77/POJK.01/2016 Tentang Layanan Pinjam Meminjam Uang Berbasis Teknologi Informasi (LPMUBTI)

Undang-Undang Nomor 19 Tahun 2016 tentang perubahan atas Undang-Undang Nomor 11 Tahun 2008 tentang Informasi dan Transaksi Elektronik (UU ITE)

Undang-Undang Nomor 8 Tahun 1999 Tentang Perlindungan Konsumen (UUPK) 